\title{
DOPAMINE $\beta$-HYDROXYLASE INHIBITOR PRODUCED BY GLOEOPHYLLUM STRIATUM AND ITS IDENTITY WITH OOSPONOL
}

\author{
Hamao Umezawa, Hrronobu Innuma, Manabu I'to, \\ Meiki Matsuzaki and Tomio Takeuchi \\ Institute of Microbial Chemistry, Shinagawa-ku, Tokyo, Japan \\ Osamu Tanabe \\ Central Institute of Takara Shuzo Co. Ltd., Kyoto, Japan
}

(Received for publication January 8, 1972)

\begin{abstract}
A dopamine $\beta$-hydroxylase inhibitor produced by Gloeophyllum striatum was isolated and found to be identical with oosponol. The inhibition is competitive with tyramine and noncompetitve with ascorbic acid. This inhibitor showed a hypotensive effect.
\end{abstract}

In screening for dopamine $\beta$-hydroxylase inhibitors we found fusaric acid to be active, ${ }^{1)}$ and also reported the activity ${ }^{1)}$ of homologs ${ }^{2)}$. In this paper, we report the isolation of oosponol from Gloeophyllum striatum, its inhibition of dopamine $\beta-$ hydroxylase, and its hypotensive effect.

A mushroom collected at Yuwandake, Amamioshima, was most closely related to Gloeophyllum among the known mushrooms. After comparing its properties with various species of this genus described by $\mathrm{ITO}^{3)}$, it was classifid as Gloeophyllum striatum. It can be cultured on an agar medium containing $2.0 \%$ glucose, $0.5 \%$ dried yeast and $1.5 \%$ agar. In our laboratory, strain number $292 \mathrm{~F}$ was given to this strain.

This strain was cultured on a wood dust medium, and inoculated into the production medium. It was shake-cultured or cultured under aeration and stirring at $27^{\circ} \mathrm{C}$ for about 7 days. The broth turned acid when the production of the active agent reached a maximum. The yield of the active agent was determined by the activity of the culture filtrate against dopamine $\beta$-hydroxylase or by thin-layer chromatography. The active agent in the culture filtrate was extracted with butanol at acid $\mathrm{pH}$ and purified by chromatography on silica gel from benzene-ethyl acetate $(2: 1$, $\mathrm{v} / \mathrm{v}$ ), followed by crystallization from warm methanol with $5 \%$ water.

The active compound had the following properties: colorless needles; m.p. 168 $169^{\circ} \mathrm{C}$; soluble in hot methanol, acetone, pyridine and dimethyl sulfoxide; insoluble in water and $n$-hexane; ultaviolet maxima in methanol at $233 \mathrm{~m} \mu, 256 \mathrm{~m} \mu$, and $335 \mathrm{~m} \mu$ ( $\mathrm{E}_{1 \mathrm{em}}^{1 \%} 272$ ) ; positive ferric chloride and Tollens; no optical activity ( $c 0.24$, methanol). The formula $\mathrm{C}_{11} \mathrm{H}_{8} \mathrm{O}_{5}$ was calculated from the analytical result (calcd. : $\mathrm{G} 60.00, \mathrm{H}$ 3.66, O 36.33; found $\mathrm{C} 59.54, \mathrm{H} 3.68, \mathrm{O} 36.06$ ) and was supported by the mass spectral analysis $(m / e 220)$. These properties were identical with those of oosponol reported 
<smiles>O=C(O)c1cccc2c(O)ccc(O)c12</smiles>

(I)

by ҮАмамото et al.4) except the melting point. The melting point of oosponol obtained from Oospora and crystallized from ethanol and benzene was reTable 1. Effect of oosponol on capillary permeability by intracutaneous in the rabbits' abdomen

\begin{tabular}{c|c|c|c|c|c}
\hline \multirow{3}{*}{ Drug } & \multirow{2}{*}{$\begin{array}{c}\text { Concentration } \\
\text { mcg/ml }\end{array}$} & \multicolumn{4}{|c}{$\begin{array}{c}\text { Capillary permeability } \\
\text { Evans blue values } \\
\text { (mean diam, mm) after }\end{array}$} \\
\cline { 3 - 6 } & & $30 \mathrm{~min}$. & $1 \mathrm{hr}$. & $2 \mathrm{hrs}$ & $4 \mathrm{hrs}$ \\
\hline \multirow{5}{*}{ Oosponol } & 40 & 16 & 35 & 57 & 67 \\
& 20 & 11 & 20 & 25 & 42 \\
& 10 & 4.5 & 10 & 21 & 28 \\
& 5 & 2.8 & 9.0 & 21 & 23 \\
& 2.5 & 1.9 & 6.8 & 11.5 & 12.5 \\
& 1.25 & 1.2 & 9.0 & 12.5 & 12.5 \\
\hline Histamine & 2 & 4.1 & 4.1 & 4.3 & 4.3 \\
Bradykinin & 0.5 & 4.2 & 5.0 & 5.4 & 5.4 \\
\hline
\end{tabular}

Each figure is average of 4 rabbits. ported to be $176^{\circ} \mathrm{C}$. However, the identity with oosponol was confirmed by the infrared spectrum and the nmr spectrum. The structure reported for oosponol by YAMAмото et al..$^{4}$ was revised by NitTA et al. ${ }^{5)}$ as above (I), and this structure was proven by the synthesis of the diacetate of oosponol ${ }^{6}$. Recently, oosponol was synthesized by UEMURA and SAKAN ${ }^{\text {7). }}$.

Oosponol was stable after heating at $60^{\circ} \mathrm{C}$ for 30 minutes in solution at $\mathrm{pH} 2.0$, but the activity decreased to $50 \%$ after heating at $\mathrm{pH} 7.0$ and to $20 \%$ at $\mathrm{pH} 9.0$.

Oosponol showed no inhibition of Staphylococci, E.coli, Pyricularia oryzae, Saccaromyces cerevisiae at $100 \mathrm{mcg} / \mathrm{ml}$. Toxicity of oosponol was as follows: $\operatorname{LD}_{50}$ to mice : $40 \mathrm{mg} / \mathrm{kg}$ intraperitoneally; $280 \mathrm{mg} / \mathrm{kg}$ orally ; $\mathrm{LD}_{50}$ to rats : $42 \mathrm{mg} / \mathrm{kg}$ intraperitoneally ; $250 \mathrm{mg} / \mathrm{kg}$ orally. It is a compound which should be carefully handled in laboratory. It caused no irritation on subjects at the first contact, however, it caused severe skin rash and severe bronchitis in persons after several contacts.

The effect of oosponol on capillary permeability was tested by the following procedure: $4 \mathrm{ml} / \mathrm{kg}$ of $0.3 \%$ Evans blue solution was intravenously injected into 4 rabbits and 5 minutes thereafter $0.1 \mathrm{ml}$ of saline containing oosponol at $1.25 \sim 40 \mathrm{mcg} / \mathrm{ml}$ was injected into the skin, and the diameter of the blue area was measured. As shown in Table 1 , oosponol even at $1.25 \mathrm{mcg} / \mathrm{ml}$ increased the capillary permeability.

The inhibition of dopamine $\beta$-hydroxylase was tested in the following reaction mixture by the method described previously ${ }^{2}$ : the reaction mixture contained $0.2 \mathrm{ml}$ of $1 \mathrm{M}$ potassium phosphate buffer, $0.1 \mathrm{ml}$ of $1 / 10 \mathrm{M}$ ascorbic acid, $0.05 \mathrm{ml}$ of $2 / 100 \mathrm{M}$ fumaric acid in $0.2 \mathrm{~N} \mathrm{NaOH}$, $0.05 \mathrm{ml}$ of $4 \mathrm{mg} / \mathrm{ml}$ of catalase, $0.1 \mathrm{ml}$ of $1 / 10 \mathrm{M}$ tyramine, $0.1 \mathrm{ml}$ of $1 / 108.5 \mathrm{p}$. N-ethylmaleimide, $0.1 \mathrm{ml}$ of the enzyme solution prepared from medulla of beef adrenal, and $0.1 \mathrm{ml}$ of oosponol solution in a total volume of $1.0 \mathrm{ml}$ with distilled water. In this raction mixture at $37^{\circ} \mathrm{C}$ for 25

Fig. 1. Effect of the intraperitoneal injection of oosponol on blood pressure of spontaneously hypertensive rats

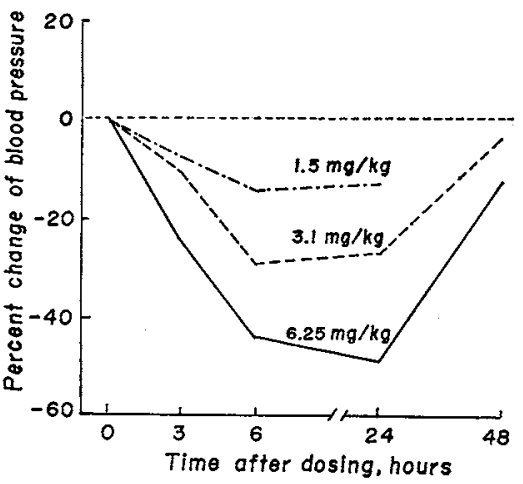


Fig. 2. Lineweaver-Burk plots of tyramine concentration against rate of hydroxylation with and without oosponol.

Incubation was for 30 minutes. The velocities are expressed as $\mu$ moles of norsynephrine formed from tyramine. The substrate concentration is expressed in moles. $A$, enzyme alone; $B$, enzyme with $1.59 \times$ $10^{-4} \mathrm{M}$ oosponol ; C, enzyme with $2.27 \times 10^{-4} \mathrm{M}$ oosponol.

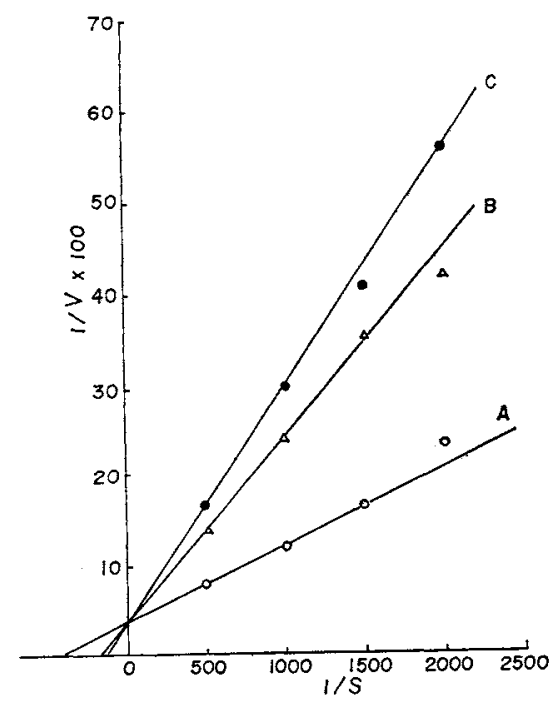

Fig. 3. Lineweaver-Burk plots of ascorbic acid concentration against rate of hydroxylation with and without oosponol.

Incubation was for 30 minutes. The velo. cities are expressed as $\mu$ moles of norsynephrine formed from tyramine. The sbstrate concentration is expressed in moles.

$A$, enzyme alone ; $B$, enzyme with $1.59 \times 10^{-4}$ $\mathrm{M}$ oosponol; C, enzyme with $3.18 \times 10^{-4} \mathrm{M}$ oospo. nol.

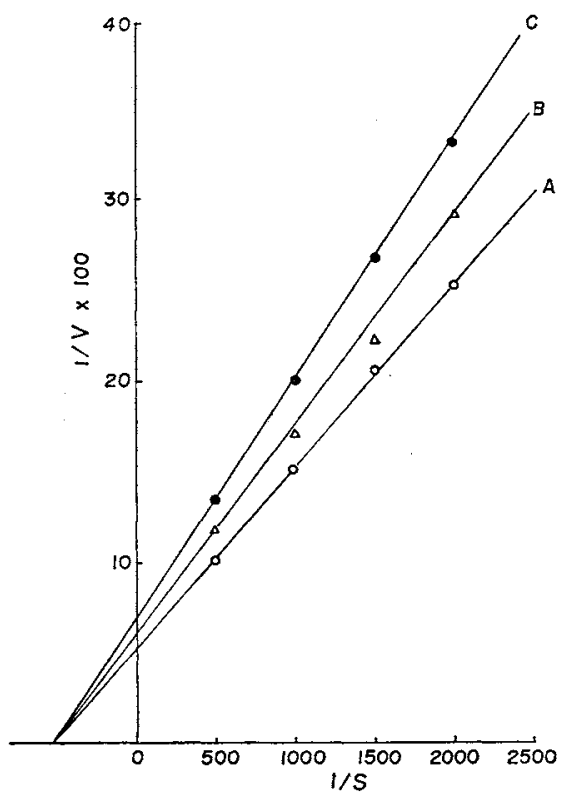

minutes, oosponol showed the following inhibition at varying concentrations: $99.2 \%$ at $100 \mathrm{mcg} / \mathrm{ml}, 52 \%$ at $50 \mathrm{mcg} / \mathrm{ml}, 35.6 \%$ at $25 \mathrm{mcg} / \mathrm{ml}, 23.2 \%$ at $12.5 \mathrm{mcg} / \mathrm{ml}$. If the active concentrations are compared with those of fusaric acid, oosponol is much weaker than the latter. However, oosponol showed a hypotensive effect in spontaneously hypertensive rats developed by Prof. K. Окамото, Medical School, University of Kyoto. As shown in Fig. 1, the intraperitoneal in jection of $6.25 \mathrm{mg} / \mathrm{kg}$ of oosponol lowered the pressure from $186 \mathrm{~mm}$ to $138 \sim 112 \mathrm{~mm} \mathrm{3 \sim 24} \mathrm{hours} \mathrm{after} \mathrm{the} \mathrm{intraperitoneal}$ injection. The intraperitoneal injection of $3.1 \mathrm{mg} / \mathrm{kg}$ lowered the pressure from $185 \mathrm{~mm}$ to $164 \sim 131 \mathrm{~mm}$.

Using the reaction mixture described above, the kinetic relation of oosponol with tyramine and ascorbic acid was examined. The Lineweaver-Burk plots of the results, as shown in Figs. 2 and 3, indicated that inhibition by oosponol was competitive with tyramine and noncompetitive with ascorbic acid.

Oosponol showed no inhibition against tyrosine hydroxylase at $100 \mathrm{mcg} / \mathrm{ml}$, when tested by the procedure described in a previous paper ${ }^{8}$.

\section{Experimental}

Production and isolation of oosponol: Ten $\mathrm{g}$ of wood dust was placed in a flask of $500 \mathrm{ml}$ volume and $60 \mathrm{ml}$ of a medium containing $2.0 \%$ glucose, $0.5 \%$ dried yeast was added. The mixture was sterilized and $G$. striatum which was grown on an agar medium containing $2.0 \%$ glucose, $0.5 \%$ dried yeast and $1.5 \%$ agar was inoculated and cultured at 
$27^{\circ} \mathrm{C}$ for 14 days. Medium $\left(2.0 \%\right.$ glucose, $0.5 \%$ peptone, $0.3 \% \mathrm{KH}_{2} \mathrm{PO}_{4}, 0.1 \% \mathrm{MgSO}_{4}$. $7 \mathrm{H}_{2} \mathrm{O}, 0.1 \% \mathrm{NaCl}$ ) was added to the flask and shaken. The mycelium suspension thus prepared $(250 \mathrm{ml})$ was used to inoculate 10 liters of a medium containing $2.0 \%$ glucose, $2.0 \%$ cornsteep liquor $\left(\mathrm{pH} \mathrm{5.6)}\right.$ in a fermentor of 30 liters volume and cultured at $27^{\circ} \mathrm{C}$ for 4 days under aeration (5 liters/minute) and stirring $(200 \mathrm{rpm})$. The cultured broth thus obtained was inoculated into 150 liters of medium in a fermenter of 300 liters volume and the cultivation was continued at $27^{\circ} \mathrm{C}$ for 7 days.

The cultured broth was filtered and 140 liters of the filtrate was extracted twice with 70 liters of $n$-butanol at $\mathrm{pH} 2.0$. The butanol extracts were combined and evaporated under reduced pressure to an oily brown residue of $310 \mathrm{~g}$. The residue was dissolved in 2 liters of ethyl acetate, the solution was filtered and evaporated under reduced pressure to give $250 \mathrm{~g}$ of a brown powder. It was dissolved in $750 \mathrm{ml}$ of a $2: 1$ mixture of benzene and ethyl acetate $(\mathrm{v} / \mathrm{v})$ and subjected to column $(5 \times 70 \mathrm{~cm})$ chromatography on silical gel $(2.5 \mathrm{~kg})$ with benzene ethyl acetate $(2: 1)$. Oosponol was detected by thin-layer chromatography: Rf 0.8 on silical gel with butanol-acetic acid-water $(4: 1: 1 \mathrm{v} / \mathrm{v})$ and $\operatorname{Rf} 0.4$ on silica gel with benzene-ethyl acetate $(2: 1 \mathrm{v} / \mathrm{v})$. Oosponol on the developed chromatogram was visualized with $0.5 \%$ potassium permanganate. Oosponol appeared in the fractions between 5.2 liters and 12.7 liters. The evaporation of this fraction gave $8.6 \mathrm{~g}$ of brownish powder. It was dissolved in $1,500 \mathrm{ml}$ of ethyl acetate, and the residue obtained by the evaporation of the filtrate under reduced pressure was crystallized from warm methanol to which $5 \%$ water was added, yielding $5.4 \mathrm{~g}$ of oosponol crystals.

\section{References}

1) Hidaka, H.; T. Nagatsu, K. Takeya, T. Takeuchi, H. Suda, K. Kojiri, M. Matsuzaki \& H. UMEZAWA : Fusaric acid, a hypotensive agent produced by fungi. J. Antibiotics $22: 228 \sim 230$, 1969

2) Suda, H.; T. Takeuchi, T. Nagatsu, M. Matsuzakr, I. Matsumoto \& H. Umezawa : Inhibition of dopamine hydroxylase by 5-alkylpicolinic acid and their hypotensive effects. Chem. Pharm. Bull. $17: 2377 \sim 2380,1969$

3) Iто, N.: On Gloeophyllum. J. Japan Mashrooms $2: 240,1955$ (in Japanese)

4) Yamamoto, I.; K. NitTa \& Y. Yamamoto: Studies on the metabolic products of Oospora sp. Agr. Biol. Chem. $26: 486 \sim 493,1962$

5) Nitia, K.; J. Ima1, I. Yamamoto \& Y. Yamamoto: Studies on the metabolic products of Oospora sp. V. Determination of the chemical structure of oosponol by synthesis. Agr. Biol. Chem. $27: 817 \sim 821,1963$

6) Shrozaki, M.; K. Mori \& M. Matsul: Synthesis of isocoumarins. III. Oosponol diacetate. Agr. Biol. Chem. 32: 42 45, 1968

7) UEmura, M. \& T. SakAN: The synthesis of oosponol and oospoglycol. Chem. Commun. 1971: 921,1971

8) Umgzawa, H.; T. Takeuchi, H. Innuma, K. Suzuki, M. Ito, M. Matsuzaki, T. Nagatsu \& O. TANABE: A new microbial product, oudenone, inhibiting tyrosine hydroxylase. J. Antibiotics $23: 514 \sim 518,1970$ 